\title{
Asymmetry as an Aesthetic Concept of Taman Sare in Sumenep Palace, Madura
}

\author{
Anggri Indraprasti ${ }^{1}$, Imam Santosa ${ }^{2}$, Prasetyo Adhitama ${ }^{3}$, Pribadi Widodo ${ }^{4}$ \\ ${ }^{1}$ Doctoral Program in Fine Art and Design, Bandung Institute of Technology, Indonesia \\ ${ }^{234}$ Bandung Institute of Technology, Bandung, Indonesia \\ 1anggri.indraprasti@students.itb.ac.id, 2imamz@fsrd.itb.ac.id, \\ 3prasetyo@yahoo.com
}

\begin{abstract}
Madurese people have a unique concept in creating art and designing objects. One example is Taman Sare which is part of the Sumenep Palace. Taman Sare was built as a bathing pool for the princess which in time it changes its function in to a decorative fish pond. Taman Sare is unique in its visual asymmetry. It's different from other buildings in the palace area that has a symmetry concept. The culture and characteristics between the Sumenep citizen and the Sumenep nobleman become its background. This paper examines the relationship between the asymmetry concept of Taman Sare and the symmetry concept of the main building of Sumenep Palace with the social characteristic and status of the Madurese people. A hypothesis emerges that the character of Madurese society tends to be dynamic in expressing design patterns, while the aristocracy applies formal rules, tends to be static in visualizing a design, especially a building. This paper describes the aesthetic value and cultural character between the two social strata of the Madurese community, especially Sumenep in the context of visual culture.
\end{abstract}

Keywords aesthetics, asymmetry, keraton sumenep, taman sare

\section{INTRODUCTION}

Sumenep Palace is the only cultural heritage of palace building that is still well preserved in East Java, specifically Madura. Sumenep Palace was completed in 1780 AD by Panembahan Sumolo with the title Tumenggung Aryo Nata Kusumo. Sumenep is in the eastern part of Madura Island which is bounded by the Java Sea in the north and east, Madura Strait in the south and Pamekasan Regency in the west [1]. Sumenep Palace is representative of Java, China, Islam, and the Netherlands acculturation. In a cultural context, imitation imitating is often done by the community. Alfre Vierkandt, a sociologist said, "Die Nachamung ist eine der Wichtigsten Grundslagen fur die Erhaltung der Kultur." This means imitation is one of the important joints in the development of culture [1]. Cultural acculturation that occurs in Sumenep Palace is the result of the composition of the community involved in the palace development process. Javanese culture cannot be avoided, because the geographical factor of Sumenep is adjacent to the island of Java and the historical factor as a "colony" of the Javanese kingdom. Most of the Madurese people adhere to Islam, therefore every building or furniture in the Palace carries Islamic values. The architecture of this building is of Chinese descent. During its construction, the Sumenep Palace was under the 
reign of Vereenigde Oostindische Compagnie (VOC). At that time the VOC had been in power for more than a century, so the role and power in the government were very strong

The palace building acculturated by various cultures was built with the concept of balance symmetry in the layout, architecture, and furniture of the palace. The use of the concept of symmetry is always synonymous with aesthetic values, harmony, and perfection. This is the characteristic of the traditional architecture in certain historical periods, especially aristocratic buildings. The application of an ideal symmetrical element pattern (the same geometric layout and shape on one or more axes or fields of symmetry) is considered as high quality in architectural and constructive solutions [2]. Meanwhile, Western landscape especially the French formal garden emphasized landscape middle axes in the blueprint, and surrounding avenue, flowers, pool, fountains, and sculpture. Everything was arranged revolving around this middle axis. In the starting point of this middle axes, it arranged tall, huge and symmetrical architecture. Architecture dominated axes, and axes dominated landscape, so architecture dominated landscape [3].

Buildings in Sumenep Palace area consist of a pavilion, madiyoso, front porch, inner room, back porch, keputren and service rooms that have a symmetrical structure. However, Taman Sare (the palace's garden) which is close to the front gate is in asymmetrical structure, not following the rules of traditional palace building. This paper will discuss the uniqueness of Taman Sare asymmetry building which is different from other buildings in the Sumenep Palace area.

\section{METHOD}

This research was conducted at the Sumenep Palace in Sumenep Regency. Sumenep Regency is located in the eastern part of Madura Island. It has 332 villages, 22 sub-districts, and 8 sub-district representatives. The purpose of this research is to describe the symmetrical and asymmetrical concept in Sumenep Palace. It uses observation, historical and descriptive method. The historical method was carried out with a literature survey and interviews with informants. Then the descriptive method is done by outlining the findings in the field and literature study. There are several theories exploring how designers understand human interpretations of the environment (and built environments). Semiotic, phenomenological and narrative theories examine the use of language, human interaction and constructed meaning relevant to understanding human interpretations of environments [4]. These methods describe the relationship between the building of the Taman Sare and the character of Madurese people. The informant in this study was one of the staff of the Sumenep Keraton Cultural Heritage and cultural history writer, and several descendants of the royal palace of Sumenep.

\section{RESULTS AND DISCUSSION}

\subsection{Symmetry - Asymmetry}

Symmetry is a concept that is intended to understand the structure, organize and simplify a complex phenomenon. However, not only the known concept of symmetry, asymmetry was found in all levels of life. Mathematically, symmetry considered interesting, but has a cold nature, stiffness, rigidity, stasis, which is less attractive. In comparison, the asymmetry is more attractive and beautiful. However, too many compositions asymmetry creates an imbalance. The concept of asymmetry commonly used in the art world in addition to the concept of symmetry. When artists use asymmetry, they also have to make a choice, because the 
symmetry can be broken in some way. In-depth understanding of symmetry and asymmetry becomes important for science and aesthetics [5].

Symmetry and asymmetry affect the aesthetic evaluation of abstract patterns. Others say that the symmetry of understanding tends to be associated with symmetry. Although small asymmetry can also be said to be beautiful, however, breaking the symmetry is not only lower the symmetry pattern but also increases complexity. While the increased complexity usually results in a higher liking, conversely, a decrease in symmetry small ones have a strong effect, so that a pattern with symmetry slightly significantly less favorable than the fully symmetrical [6]. Understanding and was supposed to be different asymmetry concept based on the cultures of each person. The contrast of worldviews reduces specific conceptual perception in various cultures, which manifest asymmetry on many levels. Asymmetry conceptual perception can be expressed through the analysis of concepts that are stored in the "collective unconscious" or to cope with language that may codify conceptual information. The stereotype of asymmetry in Russia is much lower than the stereotype of asymmetry in the US are considered positive and affirmative [7].

\subsection{History of Taman Sare}

In 1781 the Sumenep Palace complex was being expanded with permission from Netherland Colonial Government. In the front of the palace site, there are two bathing places, in the eastern part of the pavilion is called Taman Sare specifically used for the royal family and in front of the site, there is a larger bath for the citizen [8]. The sign of NC participation in the construction of the Sumenep palace can be seen from the similarity of Sumenep building with colonial buildings such as in Batavia and the big city of Java called landhuise. Landhuise buildings and colonial buildings have a visual aesthetic symmetry concept. It shows the impression of monumental, grandeur, and authority. History records, the palace building has not experienced significant physical development. Some of the changes that occurred were the addition of the Madiyoso building in the era of Sultan Sumenep; the addition of new buildings in the form of the Regent's Office in the former Keputren area; restoration of the main palace building; restoration of Taman Sare inside the palace site and the addition of buildings with shingled roofs; the function of Balai Roto in front of the palace complex as the Sumenep Museum building to store some of the Sumenep Palace's heritage [1].

However, there is missing link in Taman Sare change. Based on the sources, Taman Sare was built in a symmetrical rectangular shape. However, the current form of Taman Sare is asymmetrical with additional ornaments, see Figure 1. There is no credible record of history that can state the time and person who have made the changes of its form. Even the actual function of Taman Sare is still being debated among aristocrats. Some mentioned that Taman Sare was built as a bathing place for the princesses and others said that it was only used for water storage. The biggest possibility is the addition of the layout was carried out by Madurese people from non-aristocratic. It can be assume it happened when the VOC's authority began to weaken in Indonesia. At that time, the nobles who had previously been puppets of colonial hegemony suffered a downturn. The colonial defeat had an impact on Sumenep's aristocracy. Previously, they were lulled by the colonial with wealth and noble status. Nobles sold their property during the Dutch defeat. So it is possible to change the layout of the Sare Park by a non-aristocrat who is not bound by the rules of the palace symmetry pattern. Taman Sare has 3 (three) stairs to access the pool. Based on public trust, each ladder has a different meaning. The first ladder is believed to make youthful and found a 
life partner. The second ladder is believed to increase a career. The last is to increase faith and devotion.

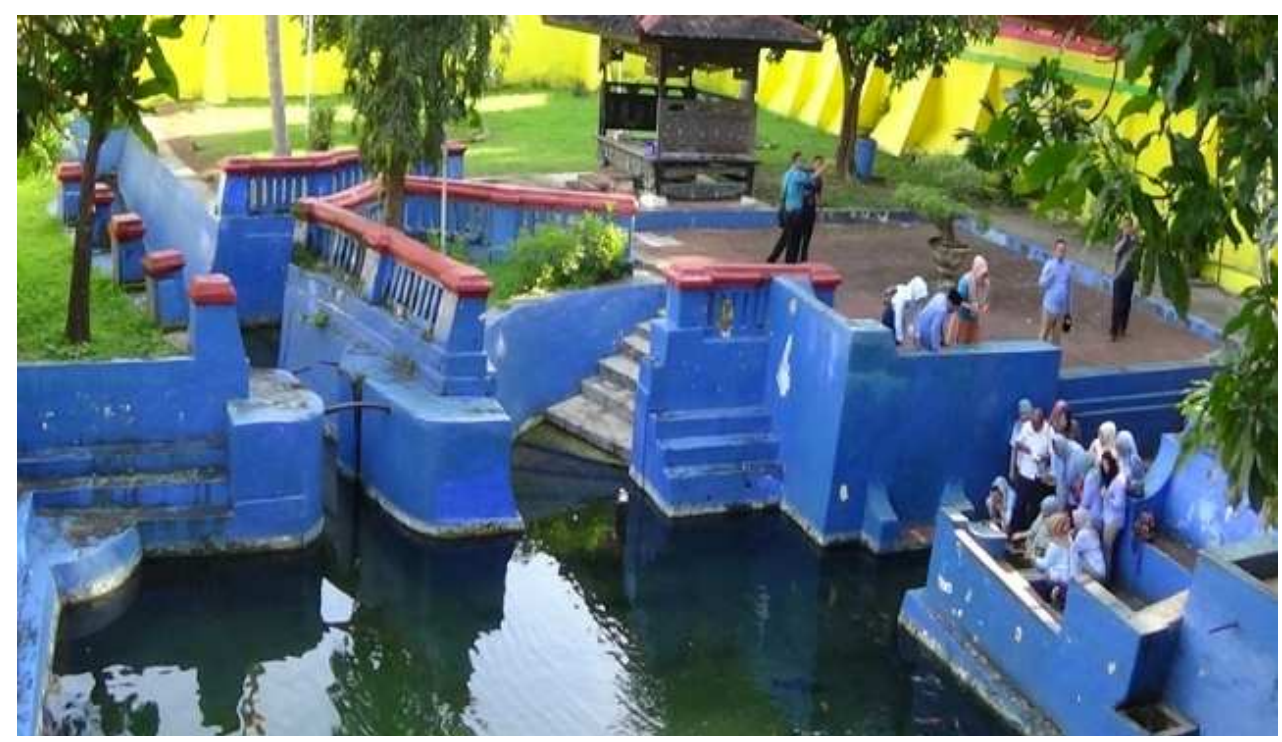

Fig. 1 Bird eye view of Taman Sare

\subsection{Taman Sare Compare to Other Building in Sumenep Palace}

In the first time the Sumenep Palace was designed with a symmetrical balance system and opened ended plan (OEP). In general, Javanese Palaces uses the concept of closed ended plan (CEP). This OEP concept is the result of colonial consideration intended to supervise noble families. In the end, Sumenep Palace has the basis of Javanese buildings with a mixture of Dutch and Chinese architecture and some Islamic values. 


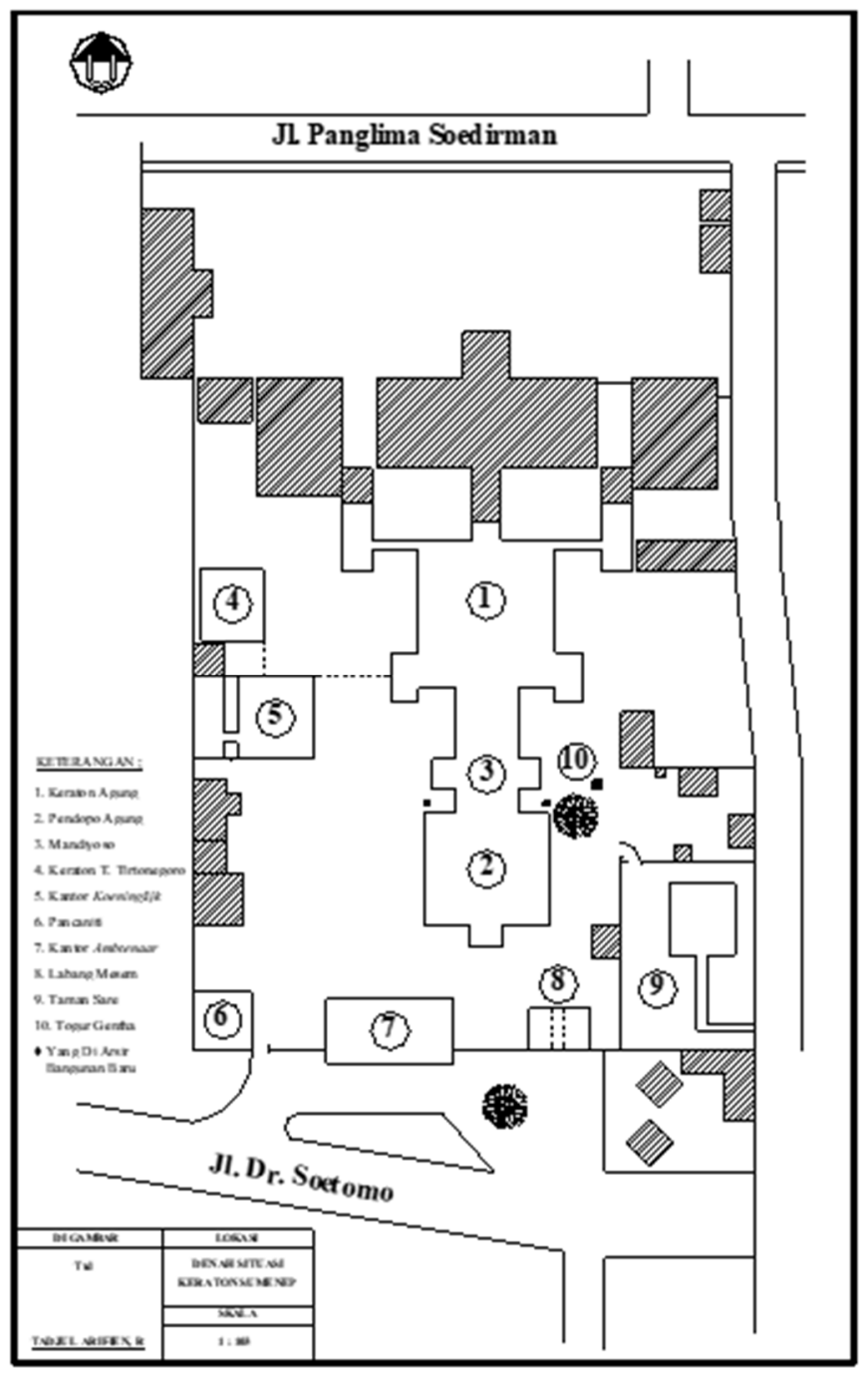

Fig. 2 Map of the Sumenep Palace area, Madura

Figure 2 shows a map of the palace area when it was first designed. The ten buildings in the palace area follow a pattern of symmetry, similarly Taman Sare building. This symmetry element is also applied in furniture and ornaments in the palace area. Keraton buildings should have a tendency to have symmetrical structures such as in Figure 3 which shows the Pendopo room and Figure 4 that shows Madiyoso area. Symmetrical balance in area and furniture shows a stable and conservative value, see Figure 5. Asymmetrical balance uses contrast in position, size, texture, color, tone, subject, and shape of design elements to show dynamism values [9]. 


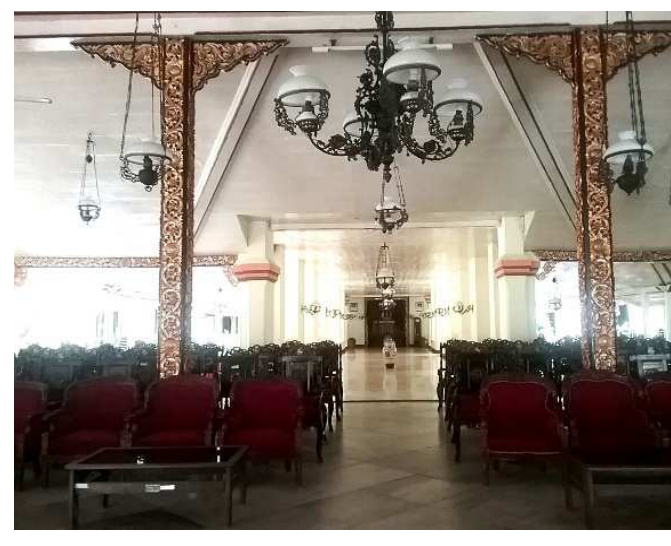

Fig. 3 Pendopo room

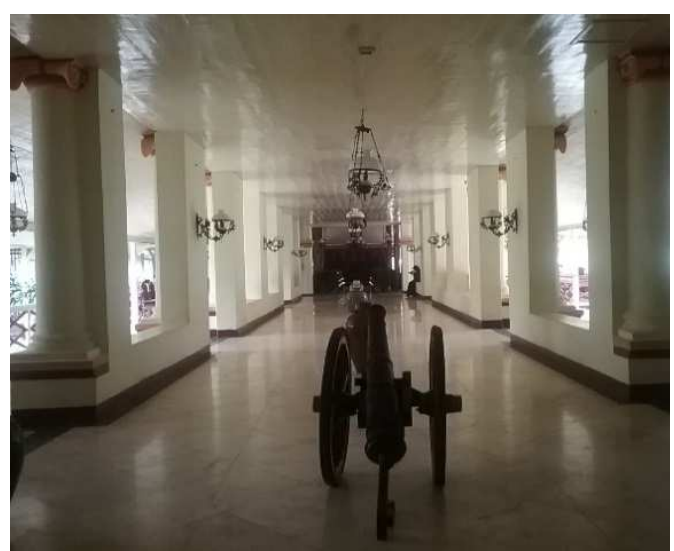

Fig. 4 Madiyoso area

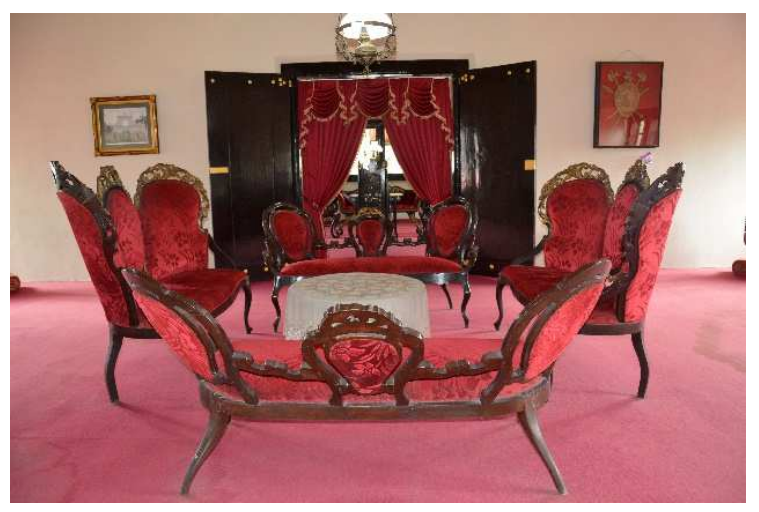

Fig. 5 Furniture on the second floor of the palace

\subsection{Taman Sare and Madurese People}

Great works of art use symbols to convey certain meanings and purposes. For example, white doves are crescent peace and stars are Islam and candles are sacrifices. This process is a transfer from the thinking of the creator through different materials and objects. Interpretation of forms or works of art can be passed formally or informally [10]. Color, appearance, shape, and texture send a sign with a certain meaning that is communicated from a creator. The meaning of the signs in creation is called semiotics. Umberto Eco put forward the hypothesis that semiotics is a culture that can be understood as the communication of art historians to decode meanings in various artifacts, to provide a complete understanding of past cultures through messages and various artifacts [11].

It was mentioned earlier that the existing Taman Sare could be made by non-aristocratic people. Madura Island is known as a disadvantaged area in the province of East Java in terms of economic prosperity. The assessment of community culture cannot be apart from community relations and ecological aspects. Madurese are known to have strong, aggressive, 
and often uncontrolled volition. One factor is the condition of agriculture in Madura which is less fertile unlike other districts in East Java [12].

In the process of creating a work, Madurese have their own uniqueness, different from Javanese society in general. For example, Madurese carvings that still survive in the village of Karduluk Sumenep and are thought to be a development of Jepara carvings in Central Java. [1] The patterns of the two engravings are very similar, but the pattern of Madura's carving is rather rough but more dynamic. It was very different from the smoother and softer Javanese or Balinese carvings. In addition, Madura batik is also known to have its own allure, including sharp coloring techniques. Madura Batik is very expressive, seen from the dominant coletan. This illustrates the freedom of expression of Madura batik artisans in pouring their imagination on a piece of batik cloth $[13,14]$. The same thing happened to Taman Sare in the Sumenep Palace. The asymmetrical shape and ornamentation of the Taman Sare room show the dynamic value and resistance of the expression of the Madurese who want to be diferent.

\section{CONCLUSION}

The form of a work of art will indicate the value that an artist wants to communicate. The Taman Sare in the Sumenep Palace complex has an asymmetrical layout that is different from other symmetrical buildings. It can be caused by the creator of Taman Sare we see today comes from non-aristocratic Madurese families which has a dynamic characteristic and expression.

\section{REFERENCES}

[1]. Wiryoprawiro Z.M. Arsitektur Tradisional Madura Sumenep dengan Pendekatan Historis dan Deskriptif. Laboratorium Arsitektur Tradisional FTSP ITS Surabaya. 1986.

[2]. P. Namicev, V. Sandeva and K. Despot. "Application of Symmetry in the Traditional Architecture of the $19^{\text {th }}$ and Early $20^{\text {th }}$ Century in Macedonia". 2013

[3]. Jellicoe and Jellicoe (1975). The Landscape of Man: Shaping the Environment From Prehistory to the Present Day. London, Thames and Hudson.

[4]. Perolini, Petra Simona. Interior Spaces and the Layers of Meaning. Design Principle and Practices. An International Journal.Volume 5 Issue 6. ISSN 1833-1874. 2011

[5]. McManus L.C. Symmetry and Asymmetry in Aesthetics and the Arts. European Review. Vol. 13. No. 2. 157-180. 2005.

[6]. Gartus A. dan Leder H. The Small Step Toward Asymmetry: Aesthetic Judgment of Broken Symmetries. i-Perception. Vol. 4, 352-355. 2013

[7]. Lebedko M.G. Asymmetry of Conceptual Perception in Russian and American Cultures. Procedia - Social and Behavioral Sciences.2016

[8]. Sejarah Sumenep. Dinas Kebudayaan Pariwisata Pemuda dan Olahraga Kabupaten Sumenep 2014.

[9]. P.C. Wijaya. "Keseimbangan Dinamik". Nirmana.Vol.2. No.1. 2000.

[10].H. Abdulhamid. Pengantar Estetik. Dewan Bahasa dan Pustaka Kementrian Pendidikan Malaysia Kuala Lumpur. 1995.

[11].S. Vihma and S. Vakeva. Semiotika Visual dan Semantika Produk. Jalasutra. 1990.

[12].A. Dharmawan, G.G. Aji and Mutiah. "Madurese Cultural Communication Approach." The $2^{\text {nd }}$ International Joint Conference on Science and Technology. 2017

[13].Mudjijono. "Lancor Hingga Mata Keteran". Jantra. Vol.11 No.2. 2016

[14].R.A.M Fibrianti and Y.M. Dora. "Pengaruh Nilai Menginspirasi Batik Tulis Madura yang Ngejreng dan Memikat Terhadap Kinerja Pemasaran”. 2012 